\title{
Análisis
}

\section{Women in integration and disintegration of Nation and Region: Indonesia and Aceh}

$\mathrm{I}$ $\mathrm{n}$ the theorizing of social movements, the place of the collective identity is both imagined and at the same time powerfully felt and enacted(Melucci, 1996 and Touraine, 2000). Such a sense of belonging, commitment and duty, enables the researcher to draw together threads that unite in a way that is evocative of James Siegel's masterpiece on Aceh - The Rope of God. The way in which women fit into such a picture is coloured by many factors, the most important of which is the perception of Islam that is believed and felt and practiced. Siegel's Rope of the 1960s was a strong male twine in which women were supportive thinner threads. The 2000s is a different picture.

This paper will examine the key social challenges in Aceh in order to comprehend the gendered nature of national integration and disintegration. The on-going activities of all women are constrained markedly by cultural practices in everyday male/female

* Researcher of University of Technology, Sydney, Australia. relationships, the years of isolation from the rest of Indonesia and the wider world, and finally, at times the draconian imposition of syariah law in matters concerning particularly the female dress code and women's public behaviour and practice.

The Rope that Siegel described in Aceh in the 1960s was a strong male twine in which women were seen to be supportive thinner threads. ${ }^{1}$ In the 2000s, such perceptions continue and were in some measure strengthened by the regional autonomy legislation of 1999. Although changes are occurring within Islam and within the women's movements of Indonesia (Robinson and Bessell, 2002), within Aceh members of political movements have required unconditional allegiance making it difficult to question structures that are basically supportive of female subservience. ${ }^{2}$ The sub-text of gender permeates all organizations and has been played out by actors whose response takes place within a context of relative isolation, social control by religious leaders, internal conflict and contestation for wealth. 
This paper will examine key social challenges to women's social movements in Aceh in order to better understand the constraints within Acehnese women work and to allow us to convey our bouquets to those women who have negotiated possibilities of action within the restricted social environment. Since the devastating tsunami of 26 December 2004, the overwhelming strictures of the political situation have relaxed (although not disappeared). Whilst not denying the joy and laughter of everyday life, the on-going activities of all women are constrained markedly by cultural practices in everyday male/female relationships, the years of isolation from the rest of Indonesia and the wider world, and finally the, at times draconian imposition of syariah law in matters concerning particularly the female dress code and their public behaviour and practice.

\section{Male/female relationships in Aceh}

The symbol for male/female relationships that is used in Aceh is that of the person, in which the man is the head and the woman is the body. ${ }^{3}$ When I questioned this analogy, I was told that there can only be one head in any institution and the family is an institution. Women are perceived to be the supporters of their men-folk, just as the body supports the head and the head tells the body what to do. Women are seen to be responsible for food and children and managing the budget for things bought within the house. They are the doers. I have watched a highly educated Acehnese man spill his drink (by accident) and do nothing. It was his wife (who had only just sat down) who raced to wipe it up and get him another drink. There was no question but that this was the right response. Men will tell their wives if they have not cooked to their liking. Men will tell women that they cannot leave the house if they consider their dress to be inappropriate. Such acts are taken in a spirit of "she is mine and I am seen as responsible for her in the eyes of all who see her". Women are perceived by men to belong to them in the same way that the body belongs to the head. Women also see themselves as belonging to their man and not as separate individuals. When such feelings arise, women pray for forgiveness and for strength to best please their man. ${ }^{4}$ When women work outside the home, they carry a double responsibility and such women rarely sit down - particularly if they have young children.

Men are seen to be responsible for knowing what is going on in the world. They read the newspapers and talk in the coffee shops. They are also seen to be responsible for earning money for the education of their children. This demand can be quite onerous and the extreme case can be likened to the western husband who works himself to the bone to pay off the mortgage on the house of his wife's dreams. Bigger and better housing is becoming an aspiration of the rising middle classes throughout Indonesia and men are by and large expected to pay for this purchase as well as the considerable (and increasing) expense of higher education, an expense which usually goes well beyond the cost of housing.

\section{Female perceptions of self}

Finding terminology to describe women's involvement in the political process in Indonesia is fraught with giving pictures that represent partial truths. ${ }^{5}$ Women who have written on feminism and the third world (Mohanty, 1991; Spivak, 1987; Afshar, 1996; Jayawardena, 1986; Alexander 
and Mohanty, 1997), have provided us with the theoretical underpinning that affirms that a range of feminisms always operates within particularized settings. They see the cultural historical (space/time) context as a necessary part of awareness and understanding. 'Western' and 'Third World' are seen as glosses that cover a broad range of beliefs and practices. The major interests of these authors have been in socio-cultural change, knowledge production and reproduction, and activism in an international context. Notions of resistance to what is the 'takenfor-granted' are seen as multi-faceted aspects of different struggles. The importance of community, of sisterhood, and of family are illustrated, and with that, the significance of agency (not 'victim') is highlighted. These intersecting factors are mapped. Indeed, the use of the words 'cartographies of struggle' (Mohanty, 1991) graphically depicts the journey that many women are making. In so doing they are creating new maps for themselves, that will inevitably influence future generations. Some of the older struggles are being retraced but with changed perceptions of significance. Political and religious ideologies have deep roots, and women's struggles tap into, and intertwine with these national, ethnic and religious cartographies.

For some women, the very notion of personal agency as distinct from their voice that comes through a male relative (father, husband or son) is new. 'One person, one vote' theoretically means that a woman can have her own voice. The last Indonesian elections opened up the political space a little more in order that this could happen (whilst recognizing that in the majority of cases, a woman would probably follow her husband's or the village leader's edict).

Indonesian women have to struggle against odds that are invisible. These odds are the entrenched practices of male power. This power is buttressed by the monotheistic religions, particularly that of Islam. It is only when the invisible boundaries are breached - when power is pushed up against the invisible wall or ceiling - that women become aware - and recognize the struggle. The social changes that are taking place within a democratic Indonesia are opening up more spaces for women as agents in their own right. The boundaries of male power may not be felt immediately; it may be an issue that has to be contended with at some point in the future, by those who are prepared to recognize their own authenticity and struggle to express it to the full.

In Indonesia women are regarded as the helpmates of men. The role of a woman in life is perceived to be that of a supporter (pendukung) to her husband. To give a small personal example: When I was in Yogyakarta in June 1999, I rang one of the people I wished to interview - a Sumatran. The man knows both me and my husband. He calls me 'Ibu Michael', as do many people who have known as both. ${ }^{6}$ His first question was asked in an almost accusatory manner, "Where's your husband?" The implication was that I should be where he was in order to give him support, and to be without him was seen to be an act of defiance. However, I was not an Indonesian. My singular presence could be excused, and after the initial banter, we had a productive interview. Had I been a relative of his, I doubt that I would have been excused so lightly. Javanese women are referred to as konco wingking, the friend at the back of the domestic alliance. There is an expectation that they should always be there.

Unmarried women are regarded as incomplete persons. Those unmarried 
women whom I know well find that their friends and family are urging them to get a husband. They argue that even if he weren't perfect - at least he would be a husband. An unmarried friend who recently returned to Indonesia with her $\mathrm{PhD}$ was told by a male colleague (a lecturer in a University) to get a husband 'even if he was only a high school graduate'. Her colleague was trying to be helpful and in his mind there were some very good husband candidates (not everyone has to have a $\mathrm{PhD}$ as he quite rightly assessed). For my friend it felt like a betrayal of his friendship, for he was not accepting her, as she was - a complete person in her own right. Another divorced friend confided that on social occasions former friends would deliberately avoid her. She overheard a woman talking about divorce as a contagious disease, with the implication that one had to beware of those who 'had it'. Islam actively promotes marriage. Celibacy is regarded as odd, and sex outside of marriage is regarded as sinful. It is seen as a religious duty to get married. (After the tsunami, many Acehnese men who had lost their wives went to the hinterland to villages they knew in order to acquire another wife.) ${ }^{7}$ An unattached elite woman who chooses to be remain unattached, is perceived to be socially questionable. These women work hard to establish professional credentials for themselves. Fortunately, large cities such as Jakarta, provide networks of sufficiently diverse peoples to offer support for difference.

Attitudes have their roots in historical perceptions. Jean Gelman Taylor's edited work of historical studies on the oft ignored role of women in the years leading to and including the Indonesian revolution has brought together a group of essays that, in a fine detailed manner, show 'snapshots of discrete moments in a half-century of dramatic change'. The stories bring women from a range of walks of life and from a range of backgrounds - including European women - into the overall picture of Indonesian history. In so doing the stories inevitably change our perception of the picture itself (Taylor, 1997).

Young women in Indonesia now are looking back to the stories of history. Older women such as Ibu S.K. Trimurti who was Minister in Sukarno's cabinet, are finding eager ears to hear of their experiences as women activists.

After the euphoric beginnings of postrevolution Indonesia, the New Order of Suharto's Indonesia became a stultifying experience for many Indonesians who wished to bring about social change for a better Indonesia. Women's organizations that were encouraged under the New Order were those that were organized along the lines of the male order of hierarchy. The many wives' organizations were for all the wives of civil servants, whether the organizations were for teachers, police, army or doctors. The organizations were called generically Dharma Wanita. Their activities were explicitly directed to making members better wives and mothers. The head of the association was always the wife of the male head. For example, at university level, this meant that 'Ibu Rektor' was always the head of Dharma 
Wanita for the wives of academic staff.

At the national level, the portrayal of women's subordination to men is the political incorporation of the notion of government as family (kekeluargaan). Saya Shiraishi has written on the various aspects of family-ism within New Order Indonesia. In relation to Bapak, Father, she writes:

In these stories, government officials - as the uncle, the husband of the second wife, and the lover of the mistress - act as the agents of God and are represented as loving fathers and husbands. These stories tell us of bapak as a popular notion. They are not concerned with individual men named Suyono or Dewanto who are criminals who happen to be government officials. The categorical logic that lies behind this narrative pattern goes something like this: the government official is by definition bapak; bapak is by definition a man of family, keluarga; and the man of family cannot be other than the loving father and husband. If he killed or tried to kill his second wife or his mistress, it is because he had to protect the happiness of his family from the woman who was the enemy of the family and therefore deserved to be killed (S. Shiraishi, 1997:103).

Shiraishi goes on to tell us that it was not just women in 'anomalous' positions such as second wife or mistress who were vulnerable. In another of the stories she cites, a first wife who pressed her husband too hard for money was killed while the second wife who had just given birth, was presented as 'undemanding', and therefore worthy of his affection, and of the nomenclature, bapak (op. cit.).

Most women activists in Aceh are those women who have paid childcare, women whose children have grown up and in some cases whose husband has died, or women who have not had children. Such women are freer to express their ideas, women whose husbands support them in their activism or young women who have not yet married and are away from their families, studying in the capital city. ${ }^{8}$ Sometimes the strain of activism tells on a woman's family relationships. The expectation of the man that she will be an obedient wife means that he expects to always be the most important person in the household. In one case where a leading woman activist received an invitation to an important dinner involving overseas guests and there was no mention of her husband's name on the invitation, he refused to let her leave the house. This was one of a number of incidents that led to her deciding to divorce him. He did not accede to her wishes when she spoke within the religious court and the case was contested. Islam does not sanction such acts and it takes a woman who is prepared to argue within the teachings of Islam and also to go against the wishes of her extended family to begin such a process. Such barriers are extremely powerful.

\section{The isolation of Aceh and then The Peace Agreement}

During the years of the conflict, Aceh was not open to foreigners. The province was not only out of bounds to those from overseas, but also to those from other parts of Indonesia. Furthermore, those Acehnese who could afford to leave the province and set up home elsewhere - in Medan, Jakarta, Yogyakarta, Kuala Lumpur, Bangkok and some as far afield as Sydney or New York-left Aceh with someone in charge of their home and their assets and fled. Wealthy families tended to make sure that their young men were taken out 
of the province for higher education or to obtain a job in another city. This depletion of the province by many who were potential young leaders led further to the sense of isolation and concern for the future by those who were left behind.

Because of the conflict, money was sought by all parties at myriads of check points along the major roads and sea ways and also from individual homes where it was thought that there was an opportunity for collecting a bundle of rupiahs. Families therefore only traveled when absolutely necessary and locked their homes early in the afternoon as they were not sure who would come knocking on their door. Suspicion and fear was rife, and for female headed households, it was a particularly difficult time because of their vulnerability. It was often impossible to tell the difference between the men who were GAM,TNI and criminal thugs. All those in Aceh knew that the process of assistance and rebuilding was hampered by the ongoing conflict, particularly those living in Aceh's rural villages where extortion went unchecked. There had been an aborted peace in 2000, but the enormity of both the tsunami-induced problems and the resultant promised resources renewed the energy to find a peaceful solution.

The outcome was assisted greatly by the facilitation of Marti Ahtisaari, Former President of Finland, and is known as the Helsinki Peace Agreement. On 15 August, 2005, the Government of Indonesia, represented by Hamid Awaludin, Minister of Law and Human Rights and the Free Aceh Movement, represented by Malik Mahmud, signed the Memorandum of Understanding. The Vice President Yusuf Kalla was a primary instigator in negotiations that led to the peace agreement.
Until the time of writing (2007), the peace agreement has held.

\section{Syariyah Law}

Syariyah Law was established initially to placate the Muslim religious leadership in Aceh in the hope that it would be perceived in Aceh as a sympathetic move by the central government. It was established under the Presidency of Abdurrahman Wahid, but was not particularly well received by the Independence movement (GAM Gerakan Aceh Merdeka). As speaking out against the law would be seen as antiIslam, all those who found and find the law draconian are constrained in what they can say publicly. Such constraints also apply to all Acehnese women, for not only would they bring disgrace upon themselves by speaking out, but also upon their husbands and their families for daring to oppose "Islam". Regional autonomy (otonomi daerah) has meant that gender relations have also become decentralized, for that law was also introduced in 1999.

Consequently there exists an underground sea of unvoiced opposition that no-one quite knows how large it is. Julia Suryakusuma, a Jakarta writer said of syariah law:

That some of these new regulations are inspired by Muslim hardliners is clear. The Acehnese laws, for example, drew inspiration from radical and controversial sharia codes introduced in Malaysian states Kelantan and Trengganu by the conservative Islamic party PAS. (Julia Suryakusuma, The Age, August 31, 2006).

In Aceh it has meant that with the introduction of syariah law, women are more tightly policed in terms of their dress. Wearing a head scarf (jilbab) is mandatory. 
I was in Banda Aceh in December 2002, December 2005 and several times in 2006 and 2007. I did not see a single woman in town without a head scarf, although within the rural villages the scenes are sometimes more like the Aceh that I knew in the 1980s where Islamic commitment was of the heart and did not have to be translated into a practice that defied the weather and agricultural demands. I went to the beach and most of the women in the water were wearing head scarves as well as their sarong and blouse. It can be argued that such coverage allows women the freedom to be themselves without men staring at them, however, my informal conversations with a number of younger women indicates that they have no choice but to conform and that there are many women who find the headscarf to be extremely hot in such an oppressive climate when they have to work outdoors and who would much prefer a return to earlier days when wearing a headscarf was a matter of personal preference and something that occurred on some days and not on others. Although some villages in the rural areas do not administer this regulation forcefully as it is seen as a central government decree, but they would all "play the game" should protocol demand.

Syariah law does not allow a man and a woman who are unmarried to be together in public. For those young women who do not have a father or a brother to drive them round, getting a ride on the back of a motorbike from a male friend or acquaintance is now against the law. Should the young woman work in the evenings as a teacher or a health worker, and need to return home later in the evening, she is also seen as breaking the law by being out on the streets alone after sun-down. Enforcement is by men and women who are employed by the Department of Religious Affairs and known as WH (Wilayahtul Hisbah).

Whilst punishment is usually by way of a fine, there have been reports of more drastic forms of punishment, particularly when women are believed to have engaged in sex prior to marriage or outside marriage. At the Aceh Women's Conference held in Banda Aceh from June 16-19, 2005, Carla Bianpoen reported in the Jakarta Post that a woman from Kutacane in the highlands of Southeast Aceh had had her fingers chopped off as a result of domestic violence (Carla Bianpoen, "Placing Women's Priorities Centre Stage in Aceh", The Jakarta Post, June 25, 2005). Women such as Rosni Idham and Samsidar have had extensive experience in coping with human rights abuses within the province, many of which are related to the intersection of the implementation of syariah law, an inherent belief in unequal gender relations and the economic climate of high unemployment.

\section{Social change, Islam and Feminism}

Interestingly, in the spate of newspaper articles on women and religion that occurred when Megawati was to become President, an article appeared on Dharma Wanita asking whether it helped or hurt its members. ${ }^{9}$ It began by quoting a high-ranking female government official "Boleh dong beda" - "It's ok friend -we can be different!" The article said that the reform era has ushered in major changes within the organization - and that there were even calls for it to be disbanded. As of 2007, that has not yet occurred, but substantive discussion has taken place in the meantime.

At the University of Islam in Yogyakarta, the Director of the Women's 
studies Unit - Siti Ruhaini Dzuhayatin has written a paper called Islamic Feminist Theology. This paper aims to open up discussion on the issue. Noting that a number of works on 'Women and Islam' or 'Women in the Qur'an' have begun this task, she seeks to identify issues that are at the heart of Islamic Feminist Theology. She places in italics the question 'How can Islamic scholars be categorized as feminist theologians?' She sees men and women having a different experience of Islam because of their different socialization. She outlines Islamic revolutionary thought by Ali Syariati of Iran who stated that consciousness of those who are oppressed is part of Islam and she implies that women can be seen to fall into this category. She sees the need for feminist knowledge, feminist methodology and feminist analysis, stating that most commentators on the Qur'an are men. She goes on to say that in interpreting God's truth, each commentator brings his own background and socialization to bear on the written word. The fact that these commentators are almost solely men means that the norm or status quo in undertaking an exegesis is that of a patriarchal perspective. For hundreds of years this has been the case, so that revealed truth has been taqlid, unquestioned acceptance of traditional religious interpretations but taqlid through masculine eyes. She quote Abul A'la Al Maududi who states that women are problematic (bermasalah) by nature. He goes on to say that women are tragic and deformed (cacat) creatures because of their biology, making them only suitable for producing children and undertaking simple household tasks (Siti Ruhaini Dzuhayatin quoting from AlMaududi in Al-Hijab, Bandung: Gema Press, 1994:167. My translation). She quite rightly describes this modern Islamic writer as a misogynist. Later in the paper she states that within Islam the image of God is the image of a male more than a female. Ruhaini has taken these ideas to the field, where she has found the reaction of men to be strong and consist of what she has termed 'feminist phobia'. She sees a need to work with sympathetic men, so that people will understand that within Islam, both males and females are considered equally valid and important. It is when ideas such as this seep into the Islam of Aceh, that change for women and men will gradually take new forms that arise from the people themselves. my

\section{Notas}

1. James Siegel, The Rope of God,

2. Unquestioned allegiance to the political group of whatever shade was particularly true during the years of conflict. These were worst during the decade of the 1990s through to the tsunami of 2004, with a brief interregnum at the end of 2002 and the beginning of 2003 when a shortlived peace accord was brokered by the Henri Dunant Centre.

3. Interview with Head of Women's Studies Centre, IAIN, Banda Aceh, December 15, 2002. This analogy was repeated by other Acehnese whom I met.

4. Discussion with married woman whose selfesteem was very low because she felt unable to please her husband. (Such attitudes are by now means confined to one particular culture. Where they are buttressed by religion, then it is usually more difficult for the woman to rebel.)

5. Cora Vreede-de Stuers wrote of 'The life of Rankayo Rahmah El Yunusiya: The facts and the image' (Locher-Scholten and Niehof, 1992) in which she examines the life of a pioneering Minang woman in the context of what she has described as fact and image. But Cora Vreede-de Stuers does not acknowledge that images can also be facts that are held in a moment of time, and it is the images that give flesh and body and energy to the skeleton of 'facts'. Having a sense of the 'image' as well as the 'facts' is what makes history come 'alive'. See Benedict Anderson's The Spectre of Comparisons, chapter 
16, 'El Malhadado Pais' where he writes of the importance of the novel in the making of nationalisms.

6. Ibu Michael is much the same as Mrs Leigh. But it is different. Ibu is a softer and more flexible word than the western 'Mrs'. The shortened 'Bu is used in all sorts of social settings whether it to be to the wife of an Indonesian dignitary or to the seller of coffee in a small café. Ibu is the word for mother. It is the word that is given to a woman who is seen to have achieved what it is necessary for women to achieve - ie to have a husband and children. A woman who is an Ibu is accorded respect. An unmarried woman is perceived to be 'unfinished'. I am also known as Ibu Barbara presumably because I am now perceived to be 'of an age'.

7. Interview with Acehnese men, Banda Aceh, April 2007.

8. The young 20 year old woman who was captured and imprisoned in January 2003 was the head of one of the NGOs - FPDRA seeking an independent Aceh. She was a student in Banda Aceh.

9. Rita A. Widiadana, "Does Dharma Wanita help or hurt its members?" Jakarta Post, Sunday June 27, 1999.

\section{Bibliography}

Afshar, Haleh, Women and politics in the Third World, London: Routledge, 1996.

Alexander, M. Jacqui and Chandra Talpade Mohanty (eds), Feminist genealogies, colonial legacies, democratic futures, New York: Routledge, 1997.

Holt, Claire, Art in Indonesia, Ithaca, Cornell University Press, 1967.

Jayawardena, Kumari, Feminism and nationalism in the Third World, London: Zed Books, 1986.

Mohanty, Chandra Talpade, Ann Russo and Lourdes Torres (eds), Third World Women and the Politics of Feminism, Bloomington: Indiana University Press, 1991.

Sen, Krishna, "Women on the Move", Inside Indonesia, April-June 1999.

Shiraishi, Saya, Young Heroes: The Indonesian Family in Politics, Ithaca: Southeast Asia Program Publications, 1997.

Siti Ruhaini Dzuhayatin, "Teologi Feminis Islam", Unpublished paper, Yogyakarta, 1999.

Sullivan, Norma, "Indonesian women in development: state theory and urban kampung practice" in Lenore Manderson (ed) Women's work and women's roles: Economics and everyday life in Indonesia, Malaysia and Singapore, Canberra: ANU, 1983.

Vreede-de Stuers, Cora, "The life of Rankayo Rahmah El Yunusiya: The facts and the image" in Ellsbeth Locher-Scholten and Anke Niehof (eds) Indonesian Women in Focus, Leiden: KITLV Press, 1992.

\section{Newspapers:}

Bernas

Jakarta Post

Kompas
MÉXICO YLACUENCADEL PACÍFICO

vol. 10, núm. 29 / mayo - agosto de 2007 